\title{
Indigenismo y romanización en Turdetania durante la República
}

\author{
María Paz Garcia-Gelabert Pérez *
}

\section{CLIMA}

El clima dominante en la Península durante el período protohistórico e histórico antiguo era más radical, más húmedo que el actual, aunque con iguales características. Inviernos fríos y veranos cálidos. Existían diferencias, como ahora, entre el clima reinante en la zona sur y levante y el de las zonas centro y norte. $Y$ este es uno de los factores de diferenciación cultural y económica, conjunt nte con otros. Un factor muy a tener en cuenta.

El clima de épocas pasadas se puede inferir por los análisis polínicos, por los análisis de flotación, por medio de los cuales se llega a conocer con facilidad la flora y fauna del momento, excelentes marcadores de las condiciones ambientales. Los textos greco-latinos son de extraordinaria utilidad.

Muchos de los autores a que hago referencia en este trabajo pertenecen a una época posterior a la republicana, -Livio, Estrabón, Trogo Pompeyo, PLINIO, Marcial, Columella, Silio Itálico, Apiano, Plutarco-, no obstante en ocasiones han manejado fuentes anteriores, como ESTRABÓN, Diodoro, Livio, PLINIO, Plutarco, etc., y el resultado final es que dibujan ya la imagen de una Bética muy urbanizada, explotada y latinizada.

No intento vaciar las Fontes, sino ofrecer una panorámica de conjunto en cuanto a como era vista la Bética por un romano, porque escritores indígenas que nos hablaran de sus propios territorios no los hubo, al menos no se han encontrado sus escritos; probablemente los mitos, las leyendas, la historia de los orígenes de los pueblos autóctonos, sus gestas, se transmitían oralmente. Se destacan algunos párrafos de los autores greco-latinos:

Con respecto a la mitad norte, Estrabón (III, 1, 2) comenta que la región septentrional es muy fría y accidentada y falta de comunicaciones

* Dep. H. Antigua. Univ. Valencia. 
con las demás tierras y por este motivo sus habitantes son poco hospitalarios, muy rudos. Esto lo vuelve a poner de relieve en I, 3, 8 al referirse a los habitantes de la montaña. Durante el largo cerco de Numancia se alude a la crudeza de los inviernos en la Meseta, como en el párrafo de Aplano (Iber. 47), con relación al invierno 153-152 a.C., pasado por Nobilior en la Gran Atalaya a $1.200 \mathrm{~m}$ sobre el nivel del mar en el corazón de Celtiberia. Y refiriéndose el mismo escritor al invierno de 140-139 a.C., dice: "Los soldados viviendo a la intemperie, expuestos a un frío glacial y no avezados al agua y al clima del pais, sufrieron de disenteria y algunos murieron (cerca de Numancia)» (ApIANo, Iber. 79-79).

En oposición, el clima era más benigno en el sur peninsular, lo que es puesto de manifiesto por los escritores, sobre todo cuando alaban la riqueza de los productos peninsulares. En Trogo Pompeyo (recogido por Justino 44, 1, 2) se significa, al comparar la Península con África y Galia, que no la abrasa el sol violento como a África, ni los vientos continuos la azotan como a Galia, por el contrario, situada entre las dos goza por una parte de una temperatura módica, y por otra de lluvias abundantes y oportunas; por ello es rica en toda clase de frutos. También indica: "La salubridad del suelo es la misma en toda Hispania, porque las corrientes de aire no están infectadas por nieblas nocivas surgidas de los pantanos. Añádase a ello las auras marinas y los vientos constantes que soplan en todas direcciones, los cuales, al penetrar en el interior de las provincias renuevan el aire de las tierras, llevando la salud a sus habitantes." $Y$ ESTRABÓN (III, 2, 13), refiriéndose a la región meridional: "La pureza del aire, la dulce influencia del Céfiro son, en efecto, caracteres propios de Iberia, que vuelta por completo al lado del Occidente, posee un clima verdaderamente templado".

E insiste el geógrafo de Amasia (III, 4, 16): “Las raíces tintóreas abundan; el olivo, la vid, la higuera y otras plantas semejantes crecen cuantiosas en las costas ibéricas que bordean Nuestro Mar, y también en las del Exterior. En cambio, las costas septentrionales ribereñas del Océano carecen de ellas a causa del frío." $Y$ nuevamente ESTRABÓN $(I, 1,4)$ al hacer alusión a los colonizaciones griegas y fenicias explica: "Mostró también (Homero) la felicidad de los hombres del Occidente, así como la templanza del ambiente».

Debido a este clima benigno, del que aún hoy se disfruta en el sur, las legiones romanas ya invernaban en la Bética durante las guerras de conquista, como sucedió en numerosas ocasiones:

Durante las guerras lusitanas: año 152 a.C., Marcelo pasó el invierno en Córduba (Polibio 35,2), después de hacer una expedición contra los lusitanos y de tomar la ciudad de Nercobriga. 
151-150 a.C., Atilio, Marcelo y Luculo invernaron en Turdetania (APIANO, Iber. 58-60).

147-146 a.C., el cuestor Vetilio pasó el invierno en Carteia mientras esperaba socorrc para enfrentarse a los lusitanos que en aquel verano habian atacado la Turdetania (APIANO, Iber. 61-63).

Invierno del 144-143 a.C., Fabio Máximo se estableció en Córduba, capital de la Ulterior (APIANO, Iber. 65). Cuando fue enviado a Hispania a combatir a Viriato, en el 145-144 a.C. antes de abrir las hostilidades marchó a Gades a hacer un sacrificio a Hércules. He ahí pues, como el culto en el templo del antiguo dios fenicio Melqart, sigue vigente en esta época y aún mucho después, como se indica más adelante.

Invierno 143-142 a.C., Quinctius pretor de la Citerior permaneció desde el otoño en sus cuarteles de invierno de Córduba ante la amenaza de Viriato que ya le había tomado algunas insignias. En este párrafo se menciona a un quaestor de Quinctius, Cayo Marcio, español de Itálica, índice de como los hispanos o hispanorromanos toman posiciones en el concierto romano (APIANo, Iber. 66). Es posible que este personaje no fuera un hispano propiamente dicho, sino descendiente de uno de los soldados asentados en Itálica, después de su fundación, llevada a cabo por Escipión en el 206 a.C., para establecer a los veteranos de la guerra púnica '. Extraña que en época temprana un hispano esté integrado en cargos que parece son particulares de romanos o itálicos. Garcia y Bellido ${ }^{2}$ cree que fuera un ibero-romano o un descendiente de los primitivos colonos de Itálica R. C. Knapp ${ }^{3}$ piensa que o es un descendiente de los primeros colonos o procede de un matrimonio mixto de itálico con mujer ibérica, pues encuentra dificil de aceptar que un turdetano tuviese mando en el ejército.

Durante las guerras celtíberas del año 97 a.C., T. Didio invernó en Castulo, porque, según Plutarco (Sert. 3), era costumbre no pasar el

Itálica, está situada en la actual Santiponce, cerca de Sevilla. En sus origenes se construyó según el patrón indigena. Sus casas eran modestas, levantadas con zócalo de piedra, pared de tapial y cubierta de madera o fibras vegetales. Los suelos eran de tierra apisonada o cantos. La vajilla que se ha hallado es característica de la cultura ibérica (ct. Luzón, J. M., "Excavaciones en Itálica. Estratigrafía en el Pajar de Artillo", EAE, n." 78. Madrid 1973 págs. 14-15). En un rpincipio fue un vicus civium romanorum, seguin parece deducirse de la inscripción de Mummius (CIL II, 1119). Durante la guerra civil entre César y Pompeyo era ya un municipium, pues se menciona a varios municipes y a un eques romanus (BA 52, 4). En época de Adriano era colonia (Gell. NA 16, 13,4).

Garcia y Bellido, A.. Colonia Aelia Augusta Italica. Madrid 1979, pág 41

KNAPP, R. C. Aspects of the Roman Experience in Iberia, 206-100 B.C. Valladolid 1977. pág. 116. 
invierno en las zonas frias de Celtiberia. Durante esta etapa de descanso invernal ocurrió un incidente entre los habitantes de Castulo y los soldados, que demuestra que aún a pesar de que habian transcurrido más de 100 años de hallarse sometidos a Roma, no estaban aún integrados en su civilización, sino que conservaban su autonomía tribal y el orgullo que caracterizaba a los hispanos. Este es el hecho: los legionarios, mientras descansaban en el invierno, maltrataban en la embriaguez a los castulonenses. Para vengarse de las ofensas recibidas pidieron ayuda a los habitantes de un poblado vecino, que se cree fuera el actual yacimiento de Giribaile, al este de Castulo, que se la prestaron y juntos atacaron a los romanos, ocasionando una matanza entre la tropa, que más adelante fue vengada merced a una estratagema de $Q$. Sertorio que a la sazón era tribuno militar de Didio.

\section{PAISAJE}

La Península fue vista por los escritores de la Antigüedad bajo la faceta de la apropiación y por ello, en general, sus condiciones ambientales, sus productos, sus pobladores, son elogiados, porque se están refiriendo a aquellas zonas meridionales y a aquellos productos que se relacionan con la colonización. Las alabanzas se dirigen sobre todo a Turdetania, la provincia Bética de los romanos a partir de la reforma de Augusto.

Como efecto del clima, la Península Ibérica, en los últimos siglos anteriores a la Era, tenía una densa vegetación, en las zonas en que no se hallaba cultivada y en las áreas cultivadas la tierra era muy fértil, dando cosechas inmejorables. Estos extremos se resaltan magnificamente por los escritores clásicos, como Trogo Pompeyo (en Justino 44, 1-2)... «Es rica (Hispania) en toda clase de frutos... En ella hay abundancia de trigo, vino, miel y aceite...". Respecto a la zona más árida, más boscosa, habitada por las tribus más fieras: Estrabón (III, 1, 2): «En su mayor extensión es poco habitable pues casi toda se halla cubierta de montes, de bosques y llanuras de suelo pobre y desigualmente regado". APIANO (Iber. 76), habla de Numancia como rodeada de valles y selvas densísimas, entre dos ríos, es decir, en una zona en que actualmente apenas se encuentra vegetación, salvo en las márgenes de los ríos. $Y$ de nuevo EsTRABÓN (III, 4, 13): "Los pobladores de las aldeas son salvajes y así son también la mayoria de los iberos; las ciudades no pueden ejercer su influjo civilizador cuando la mayor parte de la población habita los bosques y amenaza la tranquilidad de sus vecinos" (se refiere a las tribus del centro).

Según PLINIO (NH. 37, 203) Hispania es pobre en parte, pero donde es fértil hay abundancia de todo género de productos, como cerales, 
aceite, vino, caballos y metales. Incluso en las regiones desérticas, hay esparto.

\section{Limites y dimensiones}

Transmite Estrabon en III, 1, 6 «... pero la región hacia el este y sur en cuanto a fertilidad y a los productos de la tierra y mar no es inferior a ninguna parte del mundo. Éste es el país que atraviesa el Betis que viene de la misma región que el Anas y el Tagus (lo que no es correcto, procede de la sierra de Cazorla) y tiene una longitud media entre la de aquellos dos ríos. Como el Anas, también el Betis, en su principio corre hacia el oeste y después tuerce hacia el sur y desemboca en el mismo litoral que aquel río. Esta región se llama Bética del nombre del río y Tudetania del de sus habitantes... Esta región situada acá del Anas se extiende por el este hacia Oretania, por el sur hasta la costa entre la boca del Anas y las Columnas".

PLINIO (NH. 3, 9), refiriéndose al Betis, indica: «El Betis tiene su nacimiento en la Tarraconense, no como algunos han dicho, en el oppidum de Mentesa, sino en el bosque Tugiensis (en las inmediaciones de Peal de Becerro, la antigua Tugia)", es decir PLINIO situa con exactitud el nacimiento del Betis en Cazorla, “unto al cual corre el río Tader que riega el campo carthaginiensis... Tras abandonar la Ossigitania (tal vez al este de Mengíbar), entra en la Bética, donde su curso es tranquilo, viviendo sobre sus orillas, a derecha e izquierda, numerosos oppida".

Y Estrabón III, 2, 1: "Encima de la costa, acá del Anas, está la Turdetania atravesada por el Betis. La Turdetania está limitada hacia el oeste y norte por el Anas, hacia el este por algunas tribus de los carpetanos y los oretanos, hacia el sur por los bastetanos que habitan el litoral estrecho entre Calpe y Gades y por el mar que sigue hasta el Anas... La extensión de esta región no excede en longitud y anchura de 2.000 estadios».

Respecto a las dimensiones indica PLINIO (NH 3, 17): "Actualmente la Bética tiene 250.000 pasos de longitud desde el oppidum de Castulo hasta Gades y 25.000 más si se parte de Murgi en la costa. Partiendo de la costa de Carteia la latitud es de 234.000 pasos».

\section{Ciudades}

EStRabón (III, 2, 5) escribe: "Los habitantes que conocieron la naturaleza del país y sabían que los estuarios pueden ser de provecho lo 
mismo que los ríos, fundaron en los estuarios ciudades y otros establecimientos".

Según ESTRABÓN (III, 2, 1): "Hay muchas ciudades en Turdetania, siendo el número de ellas, según dicen unas 200. Las más célebres son las que están junto a los ríos y en los estuarios y en el litoral, por ser ésta la posición más favorable. Las ciudades más grandes por su fama y poder son Córduba, fundada por Marcelo y Gades; ésta por su navegación y por su alianza con Roma, Córduba por la riqueza y extensión de su territorio, contribuyendo a esto mucho también el Betis. Córduba, ya desde su principio estaba habitada por gente escogida, romanos e indígenas. $Y$ ésta fue la primera colonia que los romanos enviaron alli. Después de ésta (Córduba) y Gades, es importante Hispalis, que también es colonia romana. $Y$ aquella ciudad comercial (Gades) aún hoy florece, pero es más importante que ella Córduba por su distinción y por haber recibido hace poco soldados de César, a pesar de que no está muy bien poblada...".

Sigue ESTRABón (III, 2, 3): "Junto al Betis habitan muchos y se sube por él unos 1.200 estadios, desde el Océano hasta Córduba y la región que está algo más arriba. Y la ribera y las islitas en el río están bien cultivadas. Hay que añadir también lo bonito del paisaje, teniendo la región bosques y otras plantaciones. Hasta Hispalis suben grandes barcos de carga, casi por 500 estadios, llegándose hasta las ciudades que están más arriba de ílipa con barcos más pequeños y hasta Córduba con barcas de río, que ahora se fabrican con tablas, mientras que antes eran hechas de un tronco sólo. La región más arriba hasta Castulo no es navegable... A la derecha hay una llanura grande y alta y fértil y con grandes árboles y pastos. También el Anas es navegable, pero no con barcos tan grandes y ni tanto trecho arriba...".

Las líneas básicas de las ciudades romanas, que se asentaron sobre las poblaciones preestablecidas indígenas no parece, conforme a las investigaciones arqueológicas, que sean las mismas que las de las ciudades indigeneas. En términos generales se asientan especialmente allí donde estaban asentadas las casas de los primitivos habitantes, que desaparecen, siendo constatables, a veces, sus cimientos bajo la fábrica romana.

Cada día parece más claro que el régimen de fundaciones romanas ex novo en Hispania es extremadamente episódico y ocasional. En Turdetania algunas aportaciones demográficas itálicas se iban asentando en las ciudades preexistentes, originando en algunos casos comunidades mixtas, creando auténticos barrios foráneos, que se añadían a los antiguos. Las ciudades que así se constituian reciben el nombre de Dipolis y pueden verse en: Itálica, fundada sobre un núcleo turdetano anterior. Carteia, cuyo topónimo denuncia el origen púnico del lugar. Hispalis. Cór- 
duba, en donde ESTRABón cuenta que "romanos e indígenas eran vecinos» y donde está constatada epigráficamente la existencia de un vicus forensis. Gades, Carmona, etc.

Estos extremos los he podido comprobar en las excavaciones que realicé en los últimos años en Castulo. Sobre un nivel de habitación ibérico, se hallaba el nivel de ocupación republicano romano y encima el alto imperial. Hay que tener en cuenta que el poblamiento indígena se encontraba situado en las zonas más idóneas, y que el conquistador romano se impuso para utilizarlo.

Muchas de las ciudades hispanorromanas, como índice de que aún están ahi los habitantes autóctonos y su civilización, siguen conservando sus nombres prerromanos, por ejemplo prevalece Hispalis sobre Colonia Iulia Romula, Córduba sobre Colonia Patricia, Urso sobre Colonia Genitiva lulia, Gades sobre Urbs Iulia Gaditana ${ }^{4}$.

PLINIO, el escritor que con más precisión describe el territorio peninsular, y sobre todo el meridional, durante el Principado de Augusto y las décadas posteriores, nos transmite para tales momentos la estructura jurídica de la Bética $(\mathrm{NH} .3,7)$ : "La Bética, así llamada por el río que la cruza por la mitad, aventaja a todas las demás provincias por la riqueza de su aspecto y por cierto esplendor peculiar en su fertilidad. Tiene cuatro conventos jurídicos: el Gaditanus, el Cordubensis, el Astigitanus y el Hispalensis. Alberga en total 175 oppida de las cuales 9 son colonias; 10 municipios de derecho romano; 27 de fuero latino antiguo; 6 libres; 3 federadas y 120 estipendiarias".

\section{ECONOMIA}

\section{Cultivos}

Según Estrabón (III, 2, 4): “La Turdetania es un país sumamente próspero. Dando productos de todas clases y en gran cantidad, esta riqueza está duplicada por la exportación. Porque lo que sobra de los productos se vende fácilmente dado el gran número de barcos. Esto está facilitado por los ríos y los estuarios que, como tengo dicho se parecen a los ríos..."

Las tierras de la Bética eran en gran parte de regadio mediante los canales tartesios. Según los estudios realizados sobre los patrones de

\footnotetext{
Garcia y Bellido, A., "La latinización de Hispania", AEspA, n." 40. 1967, págs. 16-17.
} 
asentamientos béticos republicanos, parece que durante esta época la población se hallaba dispersa por el campo y la propiedad muy repartida, no obstante haber ya grandes latifundios.

Los cultivos en la Bética en época republicana eran mixtos, cereales, vid, olivo y conjuntamente la ganaderia. A partir del siglo $\|$ a.C., se produjo en la zona meridional un gran desarrollo de la vid y el olivo, que se contempla, aumentado, en el siglo siguiente. Ambos cultivos olivo y vid, llegan a su apogeo en la fase imperial, mas su desarrollo se inicia en esta primera fase.

La riqueza agrícola-ganadera de la Bética queda reflejada en las monedas. La numismática de fines de la República y comienzos del Imperio confirma plenamente la veracidad de los datos entresacados de las fuentes literarias, pues tanto espigas, como vides, olivos y otros frutos figuran como emblema en los reversos de las monedas de las ciudades: espigas en Ituci, Bailo, Carmo, Onoba, Cerit, Lastigi, Ilipa, Esuri, Calet, lliturgi, Traducta, Obulco, aquí figura también yugo y arado jungo a espiga y racimo de vid; ramas de olivo en las acuñaciones republicanas de la ciudad de Ulia.

En los siguientes párrafos de la Naturalis Historia de PLINIO se documenta la existencia de campos de olivos: 15,1 ; «... La abundancia de olivos favorece la multiplicación de los enjambres». 11, 1: «... Fenestella dijo que Italia, Hispania y también África no tenian aún este árbol (el olivo) cuando reinaba Tarquinio Prisco, es decir, el año 173 de la fundación de Roma, y que ahora ha llegado también al otro lado de los Alpes, a las Galias y al interior de Hispania" (el olivo parece que lo importaron los griegos. Antes se encontraba el acebuche del que se extraía también aceite, de peor calidad. El acebuche aún se halla en la actualidad en estado silvestre en regiones de Andalucía). 15, 8: «Respecto al aceite... Tiene en esto Italia todavia el primer puesto... luego rivalizan las tierras de Histria y de la Bética, yendo ambas a la par». Acerca de la exportación del aceite bético a la Urbe hay constancia evidente en las numerosísimas ánforas béticas halladas en las excavaciones del Monte Testaccio. 15, 17 : «... Hay aceitunas muy dulces que se secan por si mismas y que llegan a aventajar en dulzura a las uvas pasas». 17, 93: «... En la Bética no hay árbol mayor que el olivo... La Bética recoge las más ricas cosechas de sus olivos." En 17, 94 explica como los olivos en la Bética están entre las mies.

SILIO ITÁlICO $(3,402-405)$ escribe que las orillas del Betis son ricas en cereales y aceite.

Estrabón (III, 2, 6): "Se exporta de Turdetania mucho trigo, vino y aceite, no sólo en cantidad sino también muy bueno". III, 4, 16: "Las raíces 
tintóreas abundan; el olivo, la vid, la higuera y otras plantas semejantes crecen cuantiosas en las costas ibéricas que bordean Nuestro Mar, y también en las del Exterior».

Columella, (De r.r. 5, 8, 5): «El olivo no se da bien ni en llanuras ni en montañas, sino en cerros medianos, como son los de la Bética, donde se produjo y se produce todavía hoy el mejor aceite de la Península".

Según Marcial $(5,1)$ el poeta de Bílbilis, el Betis lleva corona de olivo por ser éste el cultivo principal de la Bética.

Por las fuentes literarias se conocen también otros cultivos agrícolas y hortícolas, como:

PLINIO (NH. 10, 42): «Recientemente en la Bética se ha hecho el injerto (de ciruelo) en manzano, dando un producto que se ha llamado malina. También se ha injertado un almendro obteniéndose la amygdalina". 18, 75: «Turriano llama glabrum a la especie de cebada con la que se prepara (la tisana) en la Bética y en África». 18, 95: “En Bética el trigo da el céntuplo de la sementera".

Estrabon (III, 2, 6): "Se exporta de Turdetania mucho trigo, vino y aceite, no sólo en cantidad sino también muy bueno. También se exporta cera, miel, pez, mucho kermes (cochinilla) y almagre, que no es inferior a la "tierra de Sinope"..." (este extremo está indicando el ritmo de explotación en función de exportar a que estaba sometida la provincia Bética).

Según Columella (De r.r. 10, 192) había lechugas de huerto en toda la región de Gades. Y refiriéndose a la vendimia indica (De r.r. 11, 2, 59) que empezaba el último día de agosto en la parte marítima de la Bética.

Marcial $(9,61)$, diserta acerca de un plátano que estaba en un patio en una casa rica de Córdoba y fue plantado, según se dijo por César, que estuvo tres veces en la ciudad: en 69 a.C. como cuestor, en el 61 como pretor y en 45 después de la victoria de Munda.

\section{Ganadería}

A la ganadería también se hace referencia en las Fontes. Extraña que VARRón (Rer. Rust. 2, 10,4) escriba que los túrdulos y los bástuios, es decir parte de los habitantes de la Bética no fueran aptos para la ganadería, cuando ésta se halla enraizada en el área desde época tartésica al menos, llegando hasta nuestros días, no obstante no indica el por qué no son aptos. 
Otros autores se afirman en la importancia de la ganadería, sobre todo del ganado ovino, muy importante por la lana que se comercializó en todo el Imperio:

Columella (De r.r. $7,2,4$ ) indica que las ovejas de Córduba tenian lana de color rojizo, muy apreciada. La misma es mencionada por MARCIAL $(5,2)$ que llama color de oro a la lana bética. También alude a ella en $(5,3 ; 5,5 ; 37,7 ; 8,28$ v. $5 ; 9,61,3 ; 12,18,2 ; 12,63,3-5 ; 12,65 ; 12$, $98 ; 14,133)$, y el poeta satírico JUVENAL $(12,40)$. Incluso las ovejas de la Bética, según cuenta Columella en el párrafo arriba citado se cruzaban con carneros de Átrica, que eran llevados a Gades para las fiestas del anfiteatro.

Estrabón (III, 3, 6) transmite: "Antes ha venido de Tudetania también mucha tela para vestidos, pero hoy sólo lana... Esta lana es de hermosura insuperable, pagándose por un carnero de cría un talento. Hay abundancia de tejidos finos que fabrican los habitantes de Salacia. Abundante es también la cantidad de ganado de muchas clases y de la caza, mientras faltan los animales dañinos, exceptuando los conejos..."

\section{Pesca}

La pesca era uno de los productos más importantes de comercialización, de exportación de la costa Bética, con la que se fabricaban las salazones de tradición cartaginesa: liquamen, halex, garum. Las más signficativas ciudades que se dedicaban a esta industria, impulsada en Occidente por los fenicios y cartagineses y que se prolonga hasta la época imperial, con fuerte auge en la republicana, se encuentran en el sur y sudeste, como Gades, Carteia, Malaca, Sexi o Carthago Nova. En el reverso emblemático de las monedas de las antiguas ciudades semitas del litoral suelen dibujarse, a menudo, atunes. Esta industria para producir alimentos estables de fácil exportación se remonta a los milesios en aguas del mar Negro, en los primeros momentos de su colonización en el período arcaico.

Estas son algunas de las muchas citas sobre la pesquería: PLINIO (NH. $9,68)$ “... en Gades (el pescado más apreciado es), el zeus, llamado también faber (la dorada)». NH. 9, 89-92: “... No han de olvidarse las observaciones hechas por M. Luculo (estuvo en Hispania guerreando con los celtíberos a mediados del siglo $\|$ a.C.), procónsul de la Bética, acerca de los pulpos y publicadas por Trebio Niger, que era de su séquito... Cuenta que en los viveros de Carteia había un pulpo que acostumbraba a salir de la mar y acercarse a los viveros abiertos, arrasando las salazones...". 
Y la industria pesquera lleva anexionada la explotación y comercialización de la sal, la construcción naval y la producción de redes. Y sobre la sal, tan necesaria para la industria que se menciona arriba escribe ESTRABÓN (III, 2, 6): "Tiene sal fósil y muchas corrientes de ríos salados, gracias a lo cual, tanto en estas cosas como en las de más allá de las Columnas, abundan los talleres de salazón de pescado, que producen salmueras tan buenas como las pónticas". Sigue tratando del tema de los frutos del mar en III, 2, 7.

Sobre las salazones también escribe MaRcial (7, 78 v. 1), «... Se comía mucho pescado salado. La salazón de pescado es la gran industria de la costa sur de Hispania, llevada alli por los fenicios y existente durante el Imperio romano".

Respecto a la construcción naval, se llevaba a cabo en aquelios puertos con fuerte tradición naval, como es Gades, de cuya ciudad se tratará aisladamente más abajo.

\section{Minería}

Sobre la riqueza en minerales de la Bética son muy numerosas las citas. De ello he tratado en algunos de mis trabajos ${ }^{5}$, conjuntamente con el profesor Blázquez y a ellos remito, no obstante indico algunas citas, de las más significativas:

ESTRABON (III, 2, 3): «Paralelas con el río por el lado norte, corren unas sierras llenas de metales, que se acercan al río más o menos. Hay mucha plata en la región de llipa y de Sisapo, la Vieja y la Nueva. En los Kotinai se cría cobre y oro. Estas sierras están a la izquierda para los que suben por el río... También el Anas está bordeado por sierras con minas que llegan hasta el Tagus..."

EstRABÓN (III, 2, 8): «Estando provista dicha región con tantos productos se debe elogiar y admirar no menos, sino más, la abundancia de sus metales. Porque todo el país de los iberos está lleno de ellos, mientras no todo es tan fértil y rico y menos la región rica en metales. Sucede raras veces que una región sea rica en ambos productos, y también es raro que la misma región en poco espacio sea rica en varios metales. En

Cf. entre otros, Blazquez, J. M. y Garcia-Gelabert, M. P., "El final del mundo ibérico en la Bética", Iberos. Actas de las / Jornadas sobre el mundo ibérico. Jaén 1985 (1987), págs. 349 361. Idem, "El iberismo en la ciudad de Castuo", en Los asentamientos ibéricos ante la romanización. Madrid 1986 (1988), págs. 43-54 
cuanto a la riqueza de sus metales no es posible exagerar el elogio de la Turdetania y de la región lindante. Porque en ninguna parte del mundo se ha encontrado hasta hoy ni oro, ni plata, ni cobre, ni hierro en tal cantidad y calidad...".

ESTRABON (III, 2, 14): «... Según dicen los historiadores, los cartagineses que vinieron con Amilcar Barca encontraron los habitantes de Turdetania empleando pesebres y tinajas de plata...».

Plinio (NH. 33, 96): “En casi todas las provincias se encuentra (la plata), pero es la de Hispania la más bella...".

\section{LOS HABITANTES DE TURDETANIA INMEDIATAMENTE ANTERIORES AL CONTACTO CON ROMA. CARACTERISTICAS}

Los habitantes de Turdetania son los turdetanos y los túrdulos.

Mela, $(3,3)$ señala que la Bética estaba habitada por los túrdulos y los bástulos.

MANILIO (Astron. 4, 715-717) escribe que los peninsulares en cuanto al físico, y esto se puede asociar con los habitantes en la zona sur, se distinguen de los galos y germanos por su cuerpo más rudo, delgado y nervudo. Acerca de las características físicas de los iberos también escribe TÁcito (Agrícola 11) que tenían la tez morena y los cabellos rizados.

El hombre hispano es trabajador, fornido, resistente en los trabajos. TROGo POMPEYo (recogido por JUSTINO 44, 1, 2), explica con referencia a los pobladores de la Península: "Tienen el cuerpo acostumbrado a la abstinencia y al trabajo y sus ánimos dispuestos para la muerte. Todos practican una moderación severa y firme. Prefieren la guerra al ocio, y si les faltan enemigos fuera, los buscan dentro... Este pueblo tiene ágil movimiento e inquieto ánimo, siendo para la mayoría de ellos más queridos los caballos y los arreos militares que la sangre de los suyos". Indudablemente Trogo, al citar estas características parece que está describiendo las de los pueblos menos civilizados, más auténticamente hispanos, es decir, los del norte, centro y oeste, porque por lo que se refiere a los turdetanos, parece que eran los más pacificos de entre los hispanos, como lo reconoce Livio en 34,17 . No obstante aún llegaron a rebelarse del yugo romano en el año 197 a.C., en un intento que no tuvo consecuencias para el sometimiento de Hispania (LIVIO 33, 21, 6). Al frente de la rebelión se encontraban Culchas, al mando de 17 ciudades (en el 206 a.C. contaba con 28) (LIVIO 28, 13, POLIBIO 11, 20); y Luxinio (LIVIO 33, $21,6)$, con las ciudades de Bardo (probablemente en el valle bajo del 
Betis), Carmo (Carmona), las ciudades púnicas Malaca, Sexi y otros centros costeros mediterráneos, es decir, ciudades semitas netamente antirromanas. El alzamiento contra los romanos se extendió también a la Beturia (entre el Anas y el Betis) y a Hispania Citerior.

Esta rebelión se concreta en el momento en que se regula el sistema de administración romano ${ }^{6}$.

Los abusos sobre los indígenas realizados por el sistema de administración provincial, cuya cúspide era el gobernador, la expoliación de sus tierras, de sus riquezas, la excesiva presión, propiciaron la rebelión que tuvo su origen en Turdetania. $Y$ como menos belicosos que eran los turdetanos, no tan preparados para enfrentarse a los romanos, pero no con menos ganas, probablemente, después de nueve años de explotación intensa (hago el cómputo a partir del 206 a.C., en que tras la batalla de llipa Roma se hace con el control general de la Turdetania, después de vencer a los púnicos), "Los turdetanos tomaron a sueldo 10.000 celtíberos y con estos mercenarios prepararon la lucha" (Livio 34, 17).

Más adelante parte de los abusos se resolvieron o trataron de resolverse mediante quejas al Senado romano, induciendo así algunos procesos contra gobernadores. Por Livio $(43,2)$ se conoce que el año 171 a.C. una embajada se desplazó a Roma para exponer sus quejas por los abusos de los gobiernos provinciales béticos.

Polıbio, que en el siglo \| a.C., conoció Turdetania (a partir del 133 a.C.) es citado por Estrabón (III, 1, 6) en el sentido de que el gran historiador aduce que los túrdulos son los vecinos de los turdetanos por el norte. Ahora bien, según el geógrafo griego (en el mismo párrafo), en su época no se diferencian las dos tribus, siendo en su conjunto «Los más cultos de entre los iberos, con escritura y escritos históricos en prosa y poesía y leyes en forma métrica, que según se dice datan de 6.000 años». Este texto, según García y Bellido ${ }^{>}$es dudoso, porque pudiera ser que el original en lugar de años indicase versos. No obstante hay que tener

La división entre las dos provincias fue ya un hecho desde el año 205 a.C., en que se documentan dos procónsules, mas en el 197 a.C., se regula el sistema administrativo romano y se hace definitiva esía división. La provincia Ulterior se correspondia con lo que era antiguamente el reino tartesio, es decir, fundamentalmente ef valle del Betis, las zonas mineras de Sierra Morena y la costa meridional peninsular. Turdetania quedaba incluida en la provincia Ulterior; ya a partir del año 197 a.C. Roma envía un propretor con imperium proconsular para gobernarla (Livio 32.27.6). Las provincias Citerior y Ulterior estaban separadas en principio por el rio iber y más tarde por el Saltus Castulonensis.

Garcia y Bellido. A. España y los españoles hace dos mil años. Según la "Geografia" de Strabón. Madrid 1976, nota 40, pág. 61. 
en cuenta que los turdetanos son los descendientes y herederos de la cultura tartésica y que en el ámbiente tartésico ya existía la escritura, que si bien se puede leer no es traducible.

Los bastetanos pertenecen también a la Turdetania, así como las tribus de fuera, al oeste del Anas y la mayor parte de las tribus vecinas (EsTRABÓN III, 2, 1).

En Turdetania desde luego existió un complejo panorama étnico y cultural, mucho más complejo que el que nos dibujan las fuentes, cuando los romanos entran en contacto con esta zona y después.

He aquí el panorama sintetizado y aproximado:

a) parte de la población de Turdetania debía tener un sustrato étnico indoeuropeo,

b) debió existir además un componente étnico y cultural importante semita,

b) a esto se añaden las aportaciones púnicas bárquidas.

Voy a desarrollar estos puntos brevemente:

a) Elemento étnico indoeuropeo

El texto de PLINIO (NH. 3, 13), parece que tomado de VARRón, indica que la comarca que se extiende más allá de la que limita el Betis y que llega hasta el Ana, se llama Beturia y se divide en dos partes y en otras tantas gentes, los celtici, que lindan con la Lusitania (parte de Huelva, Sevilla y Badajoz) y pertenecen al Convento Hispalense y los túrdulos -éstos serian los indigenas turdetanos propiamente dichos, situados en la zona baja del Betis, región anteriormente habitada por los tartesios-, que limitan con la Lusitania y la Tarraconense, pero que dependen de la jurisdicción de Córduba. Afirma que los célticos del sudoeste eran una rama de los celtiberos: "celticos a celtiberis ex Lusitania advenisse manifestum est sacrias, lingua, oppidorum vocabularis". A. Tovar ${ }^{8}$ acerca de este párrafo escribe que aunque PLINIO dice que su origen está claro, sacris, lingua, oppidorum vocabularis, es evidente que esta extensión de pueblos celtas no conservó la fuerza del núcleo originario, ni ofreció tan

8 Tovar, A., "Lenguas y pueblos de la Antigua Hispania. Lo que sabemos de nuestros antepasados protohistóricos", IV Coloquio Internacional de Lenguas y Cuituras Paleohispánicas. Vitoria 1985, pág. 20. 
fuerte resistencia a los romanos, ni en la onomástica muestra la misma cohesión, ni se mantiene tanto tiempo. Los célticos de la región andaluza (PLINIO NH. 3, 14) conservan todavía en época del naturalista latino sus costumbres y quizás penetraron en ella después de que la cultura tartésica se disgregó, con motivo de las razzias de lusitanos y celtíberos hacia el sur más rico. No sólo hacian incursiones y esporádicamente saqueaban, sino que es posible que grupos o individuos fueran aceptados entre las tribus de Turdetania, como asalariados en las faenas agrícolas y mineras. Desde luego como mercenarios si hay constancia de que se emplaban (LIVIO 34, 17). PLINIO, en NH. 4, 116, nombra a los túrdulos y celtici en la parte del límite entre la Bética y la Lusitania. Estrabón (III, 1, 6) dice que la región suroeste entre el Tajo y Guadiana estaba habitada por los celtici y algunos lusitanos, que los romanos llevaron allí (a estos últimos), no se sabe en que fecha, durante las guerras lusitanas, por Bruto en el 138 a.C., o por César en el 60 a.C. Según PoliBıo $(31,9,4)$ los celtici, en contacto con los turdetanos se aculturaron.

La toponimia ha conservado algunos nombres que parecen aludir a la presencia céltica en Andalucía: un oppidum Celti, Peñaflor, al este de la provincia de Sevilla, citado por PLINIO (NH. 3, 11), del Convento Hispalense. La leyenda de algunas monedas béticas es celtita(oru $\mathrm{m}$ ). Tribola es un topónimo recogido por APIANo (Iber. 62). Celtas son también las ciudades de esta zona con -briga, como Mirobriga, Nertobriga, Turobriga (PLINIO NH. 3, 14). Es también celta el nombre de otras ciudades Arialdunum (PLINIO NH. 3, 10) y Segida (PLINIO NH. 3, 14).

Las oleadas del celtíberos y lusitanos, pueblos indoeuropeos, hacia el sur, tanto por operaciones de pillaje, como por levas militares, fueron muy importantes como transmisoras de la cultura y etnia indoeuropea.

El nombre de Budar (Livio 33, 44, 4), jefe de los turdetanos, en 196 a.C., es indoeuropeo. También lo es el nombre de otro guerrero celtíbero que opera años antes, en tiempos de Amílcar (a partir del 237 a.C.), en tierras del sur, Istolacio (DIODORO 25, 10), en beneficio de los turdetanos, tal vez un jefe mercenario con su tropa. Otros nombres de jefes, que con sus hombres militan a las órdenes de los cartagineses contra los romanos en el sur, en los años 214-212 a.C. (Livio 21, 41), son también indoeuropeos, como Moeniacoeptus y Vismarus, a los que Livio llama reguli gallorum, también habla de spolia plurima gallica. Por galos se podría entender celtas, mejor celtiberos, como lo indica claramente el texto de CÉSAR (BG. I, 1), ya que la columna vertebral del ejército cartaginés estaba compuesta por tropas auxiliares mercenarias lusitanas y celtíberas (LIVIO $31,43,8 ; 52,5$ ), a uno de cuyos jefes, Belligenes (LIVIO 26, 21, 13) le regalaron tierras los romanos para recompensar su traición. En los lusi- 
tanos y celtiberos se apoyaban fundamentalmente los cartagineses. En cambio, los romanos to hacian en los iberos y turdetanos. El nombre de Culchas (LIVIO 28, 13; 33, 21, 6; POLIBIO 11, 20) es también indoeuropeo, como lo es Luxinio (LIVIO 33, 21, 6). Celta o por lo menos indoeuropeo, es el nombre de Cerdubelo (LIvio 28, 19). Debía de tratarse de un jefe de la ciudad de Castulo, pues aconsejó su rendición a Roma en el año 206 a.C.

\section{b) Componente étnico y cultural semita}

Menciona Estrabón (III, 2, 13-14), que la mayoría de las ciudades turdetanas estaban habitadas por semitas, en lo que coincide con la afirmación de PLINIO (NH. 3,8) que tomó el dato de Agripa, y con la de VARRón (citado en Plinio NH. 3, 8) que dice que la totalidad de Hispania fue ocupada por fenicios y por los púnicos.

Los semitas llegaron de Oriente por vía marítima hasta diversos puntos de la costa meridional hispana, y fundan colonias, en las que se vive el ambiente semita plenamente. Son portadores de un complejo cultural muy importante y desarrollado, originado a través de una serie de procesos múltiples de interacción. Establecieron redes comerciales que serían el vehículo de corrientes culturales, motivo, a su vez, de constante cambio cultural y de importantes procesos de transculturación. La mayor parte de los autores que han tratado el tema se limitan a señalar semejanzas formales, generalmente estilísticas con Oriente, mas éstas no son otra cosa que síntomas de contacto cultural. Rasgos de significación pasaron de Oriente a Turdetania, después de las consiguientes adaptaciones, incluyendo la fabricación de cerámica, ciertas especies de plantas domesticadas, numerosos detalles de vestido y tocado, costumbres funerarias --esto es más problemático-, metalurgia, etc.

Hay una pregunta que solamente se ha podido contestar parcialmente: ¿hasta qué punto fue significativo este intercambio comercial semitas-turdetanos para estimular el proceso ideológico?, porque si está claro que incidió fuertemente en la forma en que se reorganizan internamente las sociedades autóctonas, en función del comercio con los orientales, pero ¿incide en la ideología propia? Soy de la opinión que tales relaciones plantean problemas de préstamos culturales y aculturación que se deben clarificar en futuras investigaciones.

\section{c) Aportaciones púnicas bárquidas}

En la costa habitaban los blastofenicios, citados por APIANO (Iber. 56) en el año 155 a.C. con motivo de las guerras lusitanas «... este pueblo 
pasa por haber sido trasladado de Libia por el cartaginés Aníbal...". PTOLOMEO $(2,4,6)$ los denomina Bastuli Poeni. Avieno los menciona en el verso 241 de la Ora Maritima. Son probablemente los púnicos, que expone Agripa, ocupaban toda la costa bética (en Plinio NH. 3, 8). MeLA $(2,96)$ los sitúa en Carteia.

La vinculación de ciudades del sur con los cartagineses fue importante en algunos casos, como ocurrió con Castulo. Livio $(24,41)$ la describe en los siguientes términos, refiriéndose a los sucesos de los años 214212 a.C.:

"Castulo urbs Hispaniae valida ac nobilis et adeo coniuncta societate poenis, ut uxor inde Hannibalis esset, ad romanos defeccit”. Era pues adicta al partido cartaginés hasta el punto de que Aníbal tomó en matrimonio a una mujer de la ciudad, la que SILIO ITÁLICo (Pun. 3, 97) hace remontar a época legendaria. También Astapa fue una ciudad adicta a los cartagineses «Astapa urbs erat Carthaginiensium semper partis (LIVIO 28, 22), por lo que fue conquistada y arrasada por Escipión en el 206 a.C.

Muchas cecas del sur acuñan según el patrón de raíz púnica, antes del año 214 a.C. como un Castulo, Obulco y Kese. Las cecas denominadas libiofenicias, se documenta que funcionan en los siglos $\|$ y I a.C., y han proporcionado un buen número de monedas?.

Según M. Bendala ${ }^{10}$ el mediodía hispano estaba muy urbanizado en época prerromana, y durante la fase púnica bárquida debió experimentar un proceso acelerador considerable. Este fue un factor decisivo para la pronta implantación de Roma en la zona.

Incluso en facetas tan tradicionales, como es la religiosidad, el culto a los muertos, se aprecia la influencia púnica, que se destaca en la necrópolis de Carmona ${ }^{11}$. Es necrópolis de incineración datada en su época de apogeo a finales de la República y comienzo de la época imperial.

La necrópolis de Carmona se compone de fosas excavadas en la roca de base, además de una serie de hipogeos con cámaras y nichos a los que se desciende por escaleras o pozos. El modelo es de filiación fenicia y cartaginesa. Hay que tener presente que Carmo fue ciudad semita, y como tal conserva sus usos y costumbres, aún en fecha tan avanzada

9 Chaves, F., “Numismática antigua de la Ulterior”, IV CNN, Numismática, 30, 1980 pág. 113

(1) BENDALA, M., "La etapa final de la cultura ibero-turdetana y el impacto romanizador», en La baja época de la cultura ibérica. Madrid 1979, pág. 37.

Bendala, M. La necropolis romana de Carmona (Sevilla), 2 vols Sevilla 1976 
como la de la cronología de la necrópolis. Y no obstante en este ambiente púnico, acentuando que allí está Roma, su aristocracia provincial, destaca la denominada Tumba de Servilia que tal vez por el estilo del retrato de la difunta, sea de época de Trajano. Las formas habituales del hipogeo se combinan con un patio columnado con tendencias estilisticas helenísticas, en cuyo centro hay un estanque y alrededor, en el pórtido, los retratos escultóricos de la familia ${ }^{12}$.

\section{LOS TURDETANOS EN CONTACTO CON ROMA}

\section{Acciones bélicas}

Antes de avanzar más y ya que se ha tratado ligeramente el tema bélico, es conveniente que determine el proceso evolutivo de las contiendas en que se vieron involucrados los pobladores peninsulares, en las que defendieron y finalmente perdieron la independencia, con todas las secuelas sociales, culturales, económicas que ello imprescindiblemente lleva aparejado.

Conforme a las fuentes, los cartagineses se hallaban dominando parte de Hispania en el 270 a.C. (Polibio 1, 10, 5), mas durante la primera guerra púnica posiblemente perdieron el dominio sobre ella, que vuelven a conseguir, en parte, desde el 237 a.C., por medio de un ejército a las órdenes de Amílcar Barca (Polibio 2, 1, 5; Diodoro 25, 10; ApIANo, Iber. 5; Cornelio Nepo, Amilcar. 4; Justino 44, 5, 4). El motivo es claro, Cartago necesitaba dinero para seguir financiando la lucha contra Roma, como lo indica la contestación de Amílcar a sus embajadores: "Se habían visto obligados a guerrear en España para poder acabar de pagar las deudas que tenían con los romanos" (DIÓN CASSIO, 12, frag. 48). La conquista del valle del Betis se lleva a cabo enfrentándose a los descendientes de los tartesios, auxiliados, al parecer, por tropas mercenarias celtiberas (DıODORO 25,10$)$ y más tarde se dirigen hacia las zonas mineras levantinas, donde fundan Carthago Nova (Diodoro 25, 12; Polibio 2, 13, 1).

Por el giro de los acontecimientos son enviados a Hispania los hermanos P. y Cn. Escipión (Polibio 3, 76, 1; Livio 21, 60, 61), lo que determina que a partir de entonces las luchas entre ambas potencias sean continuas hasta la derrota púnica en el 206 a.C. En este tiempo, tanto las ciudades de Turdetania, como las tropas auxiliares hispanas, celtíberas principalmente, fluctúan sus lealtades de su bando a otro, en principio no

\footnotetext{
Blanco, A., Historia del arte hispánico. I. La Antigüedad, 2. Madrid 1981, pág. 119.
} 
motivadas por el sentido de independencia, sino prestando fidelidad al mejor postor. La deserción de los celtíberos del ejército romano, sobornados por Asdrúbal en 212-211 a.C. (Livio 35, 32) propició la derrota y muerte de los Escipiones (LIVIo 36, 143; ApIANo, Iber. 16).

En el 209 a.C. Publio Cornelio Escipión está en España y una de sus primeras medidas es tomar Carthago Nova (PoLIBIO 10, 12, 1; LIVIO 26, 27) donde los cartagineses tenían su tesoro y una gran cantidad de oro y plata. Esta rápida marcha a Carthago Nova obedece, al parecer, a obtener cuanto antes el control de las minas de plata de los alrededores, que efectivamente contribuyeron en gran medida a financiar la segunda guerra púnica. Perdidas las minas Aníbal se mantuvo a la defensiva en Italia. Este mismo objetivo es el que Ileva a Escipión a Castulo, en cuyas proximidades se encontraba, entre otras, la mina Baebelo (POLIBIO 26, 3, 8), que aún en tiempos de Plinio estaba en explotación ( $N H .33,96)$.

Toda Andalucía pasa a ser dominio romano y los cartagineses son expulsados de la Península a partir de la batalla de llipa en el 206 a.C. (Polibio 11, 20; LIVIO 28, 12, 10).

Finalizada la pugna con Cartago en Hispania, el Senado confía a Escipión la misión de arreglar los asuntos de Hispania (PoLIBIO 11, 33), de ahí se deduce que Roma ya no piensa abandonar la Península. En Hispania, Roma repetía el mecanismo empleado en la anexión suritálica antes y durante las guerras pírricas, en función de su política imperialista, es decir ocupar permanentemente aquellos territorios a los que acudía inicialmente como respuesta a una provocación, en Hispania la cartaginesa.

Y comienza la verdadera guerra en Hispania, la guerra de fuego, como es denominada por algunos autores (DIODORO 31,40 ), la guerra en que los hispanos luchan verdaderamente por su independencia, hasta la muerte, como son las guerras celtiberas, 154-133 a.C., o las lusitanas, 155136 a.C.

Hispania, a partir de su conquista por Roma, se convirtió en refugio de los políticos, uno de ellos fue Sertorio. Las campañas sertorianas, apoyadas en los pueblos menos favorecidos, celtiberos y lusitanos, a los que organizó en ejércitos disciplinados, y a la manera de Roma creó instituciones (Plutarco, Sert. 22), tuvieron un marcado aspecto económico social. Con la llamada guerra sertoriana ( 80 a 72 a.C.), que acaba con el asesinato de Sertorio por M. Perpenna (Plutarco, Sert. 26 y Pomp. 20, 3; Livio, Per. 96; Diodoro 37, 22 a; Salustiano, Hist. 3, 83; Vel Pat. 2, 30, 1; Eutro. VI, 1, 3; Ooros 5, 23, 13), de nuevo Hispania se ve asolada por los ejércitos romanos, y la Bética involucrada, ya que era la región controlada por los optimates. 
Otro acontecimiento bélico de gran importancia fue el desarrollo de la guerra civil que enfrentó a César y a las legiones de Pompeyo en Hispania.

Con motivo de este enfrentamiento se nos han legado datos preciosos para comprender mejor el funcionamiento de las ciudades meridionales durante la República. No obstante hay que hacer una fuerte labor crítica sobre ellos. Los historiadores de estos acontecimientos no son imparciales en sus ideas, por una parte son posteriores y, por otra, sus escritos están interesados en demostrar la incidencia favorable de la presencia romana en el territorio conquistado, por lo que no dudan en exagerar los caracteres de su paisaje y sus habitantes. En general hay en todos ellos un tinte político que los matiza. Está muy claro por ejemplo como interpreta César los sucesos de los que es protagonista. No falsea los hechos, es más sutil, cambia los acentos y llama la atención del lector hacia aquellos puntos que especialmente a él le interesa para que sirvan a sus fines.

Ambos, César y Pompeyo eran muy queridos por los hispanos, entre los que tenían una numerosa clientela. Pompeyo especialmente en la $\mathrm{Ci}$ terior y César en la Ulterior ${ }^{13}$. La formación de las clientelas por parte de los gobernadores y generales romanos tenían una doble finalidad, por una parte, basándose en ellas, respaldaban sus posiciones en las provincias respectivas $y$, en segundo término, respaldaban su propio poder en Roma.

Es conveniente enfatizar sobre este punto, importante de las relaciones de los hispanos con Roma. Durante las guerras de conquista y posteriormente en las guerras sertorianas y civiles, los indígenas mostraron fidelidad no al estado romano, sino a las personas. Las relaciones que los hispanos tuvieron con los grandes generales romanos, y también con los cartagineses se encuentran enmarcadas dentro de instituciones plenamente indoeuropeas y, por otra parte, helenisticas. Instituciones indoeuropeas en las que por la lealtad al jefe se llega hasta a dar la vida por él, la devoti; helenísticas en el sentido de que varios de los personajes que luchan en Hispania durante la segunda guerra púnica son prototipo

\footnotetext{
El instrumento básico para la formación de clientelas en el mundo bético de época republicana fue la concesión de los derechos de ciudadania. Su entrega se hizo, hasta donde se conoce, con el respaldo legal otorgado por la Lex Apuleia de Mario, la Lex lulia de civitae latinis et sociis danda, propuesta por el cónsul L. Julio Cesar y la Lex Calpurnia de civitate socioroum. Las concesiones anteriores a tales leyes debieron depender de las atribuciones del imperium de los magistrados. Este poderoso instrumento que fue la ciudadanía se empleo generosamente durante los periodos de guerras civiles. Una concesión significativa fue la que hizo Pompeyo a toda la familia de los Balbos. Pompeyo prácticamente dominaba en toda la Citerior. Hay que tener en cuenta que ya un antepasado. Q. Pompeyo, fue cónsul en Hispania en el 143. Su padre. Pompeyo Estrabón concedió la ciudadania a la Turma Sallvitana en el 89.
} 
de príncipes helenísticos, por su boato, por sus ambiciones, por sus especiales relaciones con los hispanos: Anibal y Publio Cornelio Escipión el Africano, denominado este último por $\mathrm{H}$. H. Scullard rey sin reino ${ }^{14}$. Este general fue de gran personalidad, y su magnetismo arrastró a los indígenas, hasta tal punto que le saludaban como a rey, como ocurrió en el año 208 a.C. (PolıBı 10, 38, 7) «... Todos los españoles que habían tomado las armas por los cartagineses en aquella jornada vinieron a rendir sus personas a la fe de los romanos, y en las conversaciones que tuvieron dieron a Escipión el nombre de rey... hasta entonces había corrido la voz sin advertirlo Publio, pero viendo que después de la batalla todos le llamaban rey hizo alto en el asunto...". Sobre sus cualidades escribe Livio $(35,1)$ ampliamente.

P. Cornelio Escipión Emiliano se llevó consigo a Hispania, en el 134 a.C. (APIANO, Iber. 84) donde se haría cargo del ejército que sitiaba $\mathrm{Nu}$ mancia, una cohors amicorum, de clientes y amigos que puede decirse es imitación de la de los reyes macedónicos y una característica de su ambición. En esta cohors, se encontraban C. Sempronio Graco, C. Mario, Q. Fabio Máximo Emiliano, su hermano, Jugurta, los historiadores Polibio, Rutilio Rufo y Sempronio Aselio y el poeta Lucilio. De la cohors amicorum más tarde nació la cohors praetoria que se encuentra ya en César.

La guerra civil tiene en Hispania dos períodos, con el protagonismo de Julio César, uno en el año 49 a.C. cuando el dictador dispone el avance hacia Hispania (CésAR, B. Civ. 1, 30. También Cicerón, Att. 9, 15, 6; ApiAno, B. Civ. 2, 40; Dión Cass, 41, 18, 3; Suetonio, lul. 34, 2; Vel Pat, 2 , $50,2)$ y el definitivo en el año 45 a.C.

En el año 49 a.C. después de la derrota de los legados de Pompeyo, M. Petreyo y L. Afranio, en la Citerior, en llerda (entre otras citas cf. CÉSAR, B. Civ., 1, 61-87; Apiano, B. Civ. 2, 42-43; Dión Cass 41, 22-23; Livio, Per. 110; Vel Pet. 2, 50, 4; Suetonio, lul. 75, 2; Front., Str. 1, 8, 9; 2, 5, 38 y 13, 6; Floro 2, 13, 28; OROS 6, 15, 6), se enfrenta César con el tercer legado, M. Terencio Varrón, en Hispania Ulterior. Varrón en la Uiterior, adicta a César, se había dedicado a construir naves de guerra, 10 en Gades, como ciudad de gran tradición marinera, con un importante puerto, y otras en Hispalis. Asimismo había trasladado el tesoro del templo de Hércules a Gades, lo que está indicando la vigencia de los cultos en dicho templo semita y la riqueza del mismo; y habia reunido grandes cantidades de trigo para enviar a L. Afranio y M. Petreyo, he ahí puesta de manifiesto, de nuevo la riqueza cerealística de la Bética. Además obligó a los ciu- 
dadanos romanos de la provincia a prometerle para la provisión de los gastos públicos una importantísima suma en metálico, 18 millones de sestercios, es decir más de 20.000 libras de plata. Varrón somete asimismo discrimina a las comunidades afectas a César en el sentido de que les carga mayores impuestos, confiscaciones de bienes, etc.

Llegado César a la Ulterior con 600 hombres, las dos legiones al mando de Cassio Longino llegarian más tarde, proclamó un edicto señalando el día en que los magistrados y principales de todas las ciudades debían presentarse ante él en Córduba (CÉSAR, B. Civ. 2, 19). Sigue narrando que no hubo comunidad que no mandase a Córduba parte de su senado ni ciudadano romano de alguna distinción que no concurriese al día señalado. Córduba y Carmo, de la que indica César que es la más fuerte plaza de toda la provincia, expulsaron a la tropas pompeyanas. Está, pues bien claro, como la mayor parte de la Bética se decanta por César. Y no sólo la población y sus magistrados, sino las propias legiones de Varrón, una de las cuales, la denominada "vernácula», levantó sus enseñas del campamento ae Varrón y se situó en Hispalis, alojándose en el foro en sus pórticos (CÉSAR, B. Civ. 21, 20), lo que está indicando como en tiempo republicano ya existían complejos civiles públicos de importancia, índice de romanización, puesto que para alojar a los miembros de una legión, la plaza debía de tener unas considerables dimensiones. Posteriormente los legionarios fueron alojados en casas particulares. Finalmente Varrón se entregó a César en Córduba (CésAR, B. Civ. 2, 20. También Dión CASS. 41, 23, 2; Livio, Per. 110; Floro 2, 13, 29; Oros. 6, 15, 7).

Nuevamente se enfrenta César personalmente en Hispania con los hijos de Pompeyo en el año 45 a.C. Muere Cn. Pompeyo y Sexto huye a Celtiberia (cf. entre otras citas B. Hisp. 19-42; LIVIO, Per. 115; VEL PAT. 2, 55, 2-4; Plutarco, Caes. 56, 1-6; Floro 2, 1, 78-87; Eutr. 6, 24; Oros., 6, 16, 7-9).

César premió a las ciudades adictas (CésAR, B. Civ . 2, 21): «... Dio las gracias a todos en general: a los ciudadanos romanos por su celo en procurar asegurarle la ciudad; a los españoles por haber expulsado a las guarniciones (cf. la dicotomía entre españoles y ciudadanos romanos); a los gaditanos por haber desbaratado los proyectos del adversario... manda en Gades que el tesoro del templo de Hércules sea restituido a su lugar de origen...". A los habitantes de Cádiz concedió la ciudadanía romana, orden que fue ratificada mediante la lex lulia de civitate gaditanorum (DION CASS. 24; LIvio, Per. 111).

Efectivamente, con anterioridad a su marcha a Roma realiza en Hispania una importante reforma que tuvo, sobre todo, repercusiones en la provincia Ulterior (LIVIO, Per. 116; Vel PAT. 2, 56, 2; PLINIO, NH. 14, 17, 
97; Suetonio, Iul. 37, 1; Floro II, 13, 89; Dión Cass. 43, 42, 1). Seleccionó ciudades peregrinas con un urbanismo desarrollado, potencial demográfico, élite latinizada y contingente de ciudadanos romanos, para elevarlas a la condición de municipio. El más importante municipio cesariano es Gades, que adoptó el nombre de Urbs lulia Gaditana. También hay que citar Asido e Itálica y tal vez Castulo, cuyos habitantes, según PLINIO, son denominados Caesarini luvenales. En otros casos, incorporó veteranos a su población y las elevó al rango de colonias, como ocurrió con Urso, que recibió tras la batalla de Munda el asentamiento de una deductio de colonos, y pasa a ostentar la categoría de colonia civium Romanorum. Otras colonias cesarianas son Hasta Regia, Hispalis, Ucubi, Itucci.

\section{índice de romanización}

Los romanos, cuando se enfrentan a las tropas púnicas en Hispania, a partir del año 218 a.C., aparecen como liberadores ante los ojos de los naturales hispanos, y éstos conjuntamente con las tropas romanas, se oponen a los púnicos. Una vez que son vencidos y expulsados los púnicos, los que fueran liberadores pasan a ser conquistadores y explotadores.

Con anterioridad a la reorganización del 197 a.C. la administración de Hispania es muy provisional, apenas organizada. Privan, sobre todo los acuerdos personales de los generales con los diversos jefes de tribu o sus asambleas. Mas ya a partir de la citada fecha se establecen progresivamente medidas de presión, para controlar, para supervisar la producción. En la provincia Ulterior, según A. del Castillo ${ }^{15}$ los romanos utilizaron un sistema de supervisión basado en las ciudades, de forma que Castulo, Obulco, Carmo y Gades serían los centros supervisores de las diversas áreas constituidas.

El proceso de asimilación de la cultura romana en el área meridional en la Turdetania fue más sencillo y más rápido que en las regiones del interior, porque los indígenas de esta zona ya habian asimilado rasgos culturales de otros pueblos con los que anteriormente habian entrado en contacto, fenicios, griegos, cartagineses.

Las culturas autóctonas coexistieron con las formas de vida romanas, pero puede decirse que sostenían una contienda que desde el principio

Blazquez, J. M. y Castillo. A. del, Prehistoria y Edad Antigua. Manual de Historia de España I. Madrid 1991, pág. 333 
estaba perdida irremisiblemente. Un ejemplo muy doméstico es el que aporta VARRón (de ling. lat. 5, 162) que escribe hacia el 60 a.C.: hablando del atrium de la casa romana y de las habitaciones dice que antes, cuando todavía no se cenaba en el piso superior sino en el bajo una de estas habitaciones se llamaba cenaculum y que este nombre se conservó en algunas ciudades de Italia y en Córduba (la capital de la Bética), lo que manifiesta que en Turdetania, donde la cultura romana habia entrado desde aproximadamente el 206 a.C. se conservan costumbres antiguas.

Roma respeta aquellas instituciones autóctonas que no se oponen a su política e incluso consolida, protege, las que la favorecen como es la institución de la devotio. Asimismo acepta la colaboración de las aristocracias nativas y a cambio respalda su preeminencia y posición dentro de las ciudades.

Un pueblo de bagaje cultural diferente, ni mayor ni menor, a aquél al que se halla sometido, no pierde tan pronto la propia identidad, quizás si exteriormente, en su relación con el dominador, pero no las pautas de conducta familiar, interpersonal dentro de su esfera de acción, en su aldea, en su casa. Desde luego no entra dentro de los comportamientos tribales hispanos el cambio en cuanto a creencias religiosas, a contenidos simbólico-rituales, por lo menos en las primeras generaciones. Ejemplos de esto se siguen observando en la actualidad cuando se estudian los pueblos sometidos a naciones con diferente grado cultural.

Al intensificarse la explotación, con la implantación de colonias de veteranos, y se concede el estatuto municipal, la romanización comienza a surtir sus efectos con más intensidad.

Cuando Estrabón en $111,2,15$ señala que los turdetanos han sido completamente romanizados de manera que ya no se acuerdan de su idioma, y usan vestidos romanos, indudablemente está exagerando con la retórica propia de aquéllos que no conocen la problemática, los mecanismos de aculturación y que quieren demostrar que la presencia ro. mana en el territorio conquistado y explotado ha sido beneficiosa hasta el punto de integrar a sus habitantes en la latinidad. ESTRABón vive y escribe a caballo entre las dos eras, y unos años antes, aproximadamente hacia el 44 a.C., CICERRÓN (De divinatione 2, 131), significa "..tamquam si Poeni aut Hispani in senatu nostro loquerentur sine interprete", es decir, los hispanos conservaban su lengua y apenas conocian el latín porque habian de usar intérprete, claro que Cicerón no especifica de qué pueblos se trata, pero puede pensarse no con certeza absoluta, pero si con evidencias más o menos fuertes, que entre estos hispanos se hallaban los turdetanos. El latín se hablaría en los núcleos urbanos y en el seno de 
las clases sociales más altas ${ }^{16}$, que serian las que conocieran los autores en los que se apoya ESTRABÓN. Y también plausiblemente en el medio mercantil, que habría de adaptarse a los modos culturales de los conquistadores, para llevar a cabo con éxito sus transacciones, como puede ser el caso de las ciudades costeras con una larga tradición comercial y marítima, que conservan en época romana, cual es Gades. El vulgo hablaría su idioma materno. Abundan las manifestaciones arqueológicas que acreditan que existía un bilingüismo, no un idioma único, como son las acuñaciones monetales con letreros ibéricos o fenicios o las inscripciones en lengua vernácula escritas en alfabeto latino ${ }^{17}$.

\section{RESTOS MATERIALES}

Según A. Blanco ${ }^{18}$ Roma cuando llega a la Península aún carece en su propia metrópoli de un arte propio antes del siglo I a.C., lo que le inclina a suponer que el nacimiento de talleres provinciales hispánicos no se produce por irradiación de la Urbe, sino de sus dominios itálicos o galorromanos.

En la plástica pervive durante mucho tiempo la tradición local y es de observar como el helenismo, del que se influencian las obras romanas, se confunde con el helenismo que llega a la plástica indigena aportado por los bárquidas. Es una época en que el ambiente artístico- del helenismo irradia a todo el Mediterráneo.

La escultura zoomorfa, los animales guardianes, que generalmente formaba parte de las estructuras importantes en época plena ibérica, a partir del siglo vi a.C., pervive en esta fase de transición, aun con ciertas características estilísticas diferentes, que vienen dadas por una simbiosis del arte autóctono con el helenístico aportado por la romanización y antes por los púnicos. Existe un mayor movimiento en las figuras y un tratamiento más detenido de determinados rasgos anatómicos en los animales. Esto también viene dado por el conocimiento que de ellos poco a poco se va teniendo, como es el caso de los leones, que ahora pueden llegar a contemplarse al natural en las venationes de los anfiteatros. Por lo que respecta al significado iconográfico, el león sigue manteniendo un carácter esencialmente mágico funerario de guardián de las sepulturas contra los agentes exteriores y protector del reposo del difunto. El arte helenístico

Garcia y Bellido, A., La latinización de Hispania, págs. 3 y ss.

Ibidem, pág. 13.

Blanco, A., Historia del arte hispánico I. La Antigüedad, 2, pag. 128. 
introduce una variante, adoptada en la Bética, el león se convierte también en el simbolo de la propia muerte ${ }^{19}$, devoradora de seres vivos, de ahí que se le represente sujetando bajo sus garras una víctima que suele ser un animal de mediano tamaño, herbivoro o bien un ser humano, como sucede en los leones de Bornos, Utrera, Mesas de Asta, Úbeda la Vieja y Jaén. Este tipo más realista sigue formando parte de la escultura funeraria romana ${ }^{20}$. Los leones de la Bética, como los de Bornos, los de Asta Regla, tienen unas fuertes influencias de los leones que se encontraron como guardianes en la tumba de los Stronii en Pompeya, datados en época de Sila.

Los mármoles son extraídos de las canteras del área, que fueron explotadas por los romanos, como las encontradas en Pagus Marmorarius (Almadén de la Plata, Sevilla), Alconera, Estremoz, Macael, Cabra.

Una creación netamente romana, no influenciada por el arte griego, es la del retrato, que en las provincias arranca de los retratos que se crearon en la época que se corresponde con Sila hasta el segundo triunvirato, es decir entre los años 80 y 31 a.C.

Los origenes del retrato parecen remontar a las mascarillas que se tomaban de los difuntos, para conservarlas con veneración en las moradas romanas o bien en los retratos de los antepasados que periódicamente se sacaban en procesión mientras se cantaban los cargos y los honores recibidos en vida por los difuntos que se veneraban. Ahora bien, el retrato no es una mascarilla, va más allá. En el retrato romano destaca un gran realismo. El artista no matiza los defectos de la persona, los expone. En el retrato republicano se da culto a la vejez, a la virtud antigua de los primeros tiempos de la República. Son retratos de los nobles, de los senadores, de los pater familias sean o no patricios. La Bética ha proporcionado algunos retratos de época republicana, no demasiados, pero buenos ejemplares, como los de Córduba, Gades y Jerez de la Frontera.

Los retratos femeninos no son tan naturalistas, a pesar de ello la vejez también se representa, como una cabeza de El Coronil en el Museo de Sevilla. No obstante existe una cierta tendencia a rejuvenecer a la mujer al modo helenistico, como las cabezas femeninas de Carmona y El Coronil, en Sevilla, que pertenecen a una escuela local.

De época republicana son los relieves de Osuna. Fueron interpretados por A. García y Bellido ${ }^{21}$ como pertenecientes a un monumento ligado a

Chapa. T., La escultura ibérica zoomorfa. Madrid 1984, en nota 20, pág. 259.

Ibidem, pág. 143.

Garcia y Bellido, A. Arte iberico en España. Madrid 1980, pág. 59. 
los acontecimientos de la batalla de Munda. P. León ${ }^{22}$ es del parecer que su carácter es funerario, quizas no todos correspondientes a las mismas tumbas y por el hecho de estar empotrados en la muralla republicana, fabricada entre los anos 50-45 a.C., establece tal fecha como término ante quem para la ejecución de los mismos. Según B. Griñó y R. Olmos ${ }^{23}$, corresponderían a un monumento funerario turriforme.

Las escenas reproducen, con diverso grado de naturalismo, competiciones, procesiones con antorchas, libaciones y los juegos que se celebraban con ocasión de la muerte de personas importantes. Un ejemplo de tales funerales es la narración que Apiano (Iber. 71) hace del de Viriato: “...El cadáver de Viriato, magníficamente vestido, fue quemado en una altísima pira, se inmolaron muchas víctimas, mientras que los soldados, tanto los de a pie como los de a caballo, corrían formados alrededor de sus armas y cantando sus glorias al modo bárbaro... terminado el funeral, celebraron combates singulares sobre su túmulo." Estas honras fúnebres pueden verse reflejadas en los relieves de Osuna.

En las figuras hay. según P. León ${ }^{24}$ dos tendencias estilísticas: una de carácter arcaizante de cuño local, otra retórica, efectista, evocadora de reminiscencias helenísticas de influencia romana. La primera se caracteriza por un acertado, aunque simple y lineal estudio del natural, en el que se descuidan las proporciones anatómicas y minuciosidad en detalles de vestido.

En un sillar de esquina se esculpieron dos figuras femeninas contrapuestas, una auletris con ancha falda de pliegues hasta los pies, con torques al cuello y cinturón metálico con tema en SS, frecuente en la decoración ibérica, principalmente en las placas con influencias meseteñas. Su acompañante está envuelta en una capa. En otro sillar se representa a otras dos, portadoras de ofrendas, que se cubren con ropas talares y largo velo. La de la izquierda sostiene, al parecer, una antorcha, el relieve está muy destrozado, y la de la derecha un vaso de ofrendas similares a los de plata, que se encontraron en tesoros ocultos en estos tiempos, fechados en épocas muy bajas de la cultura ibérica. De la misma serie son los dos guerreros enfrentados con armamento esencialmente indígena, escudo largo de la Tène, falcata, casco de cuero empenachado

LEON, P. "Plástica ibérica e iberorromana", en La baja época de la cultura ibérica, pág 184. Para la datación de los relieves véase Conzo, R., Osuna de Pompeyo a César. Excavaciones en la muralla republicana. Sevilla 1977.

Grino, B de y Olmos. R.. La pátera de Santisteban del Puerto (Jaén). Estudios de Iconografía I, MAN, 1982, pág. 100

LEON. P., Plástica iberica e iberorromana. pág. 186 
hasta los hombros, sin duda el caso lusitano (ESTRABón III, 3, 6). Un quinto relieve ofrece la figura de un jinete al galope con la falcata en la mano. Este conjunto de soldados puede referirse a los mercenarios celtíberos que actuaban como tropas auxiliares tanto al servicio de los turdetanos como de los romanos o cartagineses. Se fechan estos relieves a finales del siglo $\| 1$ o comienzos del siglo $\|$ a.C. ${ }^{25}$.

La segunda serie evidencia la presencia romana, más por la temática que por la ejecución, en la que se detecta aún el criterio de los talleres autóctonos, apegados a sus técnicas tradicionales, aunque un mayor movimiento y soltura son indicios seguros que acusan las novedades impuestas y difundidas durante el período helenístico. Los motivos se refieren a escenas militares en las que se han representado a los guerreros hispanos con la caetrae, el pequeño escudo redondo hispano y un segundo formado por soldados romanos, con túnica, loriga, ocreae y calligae, entre ellos destaca el cornicen tocando un gran cuerno. También se esculpió un acróbata y un individuo caido en tierra sobre el que un león posa su garra. Este último tema se relaciona con la serie de leones devoradores de hombres o animales a que he aludido más arriba.

La segunda serie es del mismo taller probablemente que otros relieves procedentes de Estepa, consistentes en dos legionarios y la conducción de una víctima al sacrificio, fechados, atendiendo a los datos de tema, técnica y estilo en el primer tercio del siglo I a.C. ${ }^{26}$. Los de Osuna pueden oscilar hasta mediados del siglo। a.C., término ante quem impuesto por la construcción de la muralla, aunque también sería válida la cronología de Estepa, puesto que las escenas militares plasmadas en ellos podrían aludir a las novedades tácticas introducidas durante las campañas sertorianas, tan decisivas para los habitantes hispanos.

En Castulo se han hallado numerosas inscripciones, pero la mayoría de épocas posteriores a la República. La única de este período se trata de un sillar de piedra caliza, que se conserva en el Museo Arqueológico Nacional de Madrid. Es una prueba evidente de los avances de la romanización entre las poblaciones del sur de Hispania. En ella está escrito: M. Folvi Garos / A. Uninaunin. VJ bag. Marc. La. L. / Uninimit / sierouciu (ClL 3302). M. Folvi son praenomen y nomen latinos, pero lleva un cognomen Garos, que es indígena. Indígenas son también A. Uninaunin Vegag y Marci La, lo cual está indicando la supervivencia de la lengua local. Al 
dorso de la piedra se lee: P. Cornelius P. L. Diphilus (CIL 3294), seguido de Castlosaic, que es el equivalente indígena de castulonensis.

Los pavimentos de mosaicos no abundan en época republicana. Destacan los de opus signinum. Uno de ellos es el recobrado en Puente del Obispo (Jaén), no lejos de Castulo. En esta ciudad han aparecido restos, muy deshechos, de tales mosaicos en la zona norte de la ciudad. El pavimento de Puente del Obispo se compone de mortero de cerámica machacada sobre el que se incrustaron teselas blancas, colocadas de manera muy descuidada, formando series de cuadrados. Otro pavimento de opus signinum se encontró en Itálica ${ }^{27}$, conservado en la colección de la Condesa de Lebrija en Sevilla.

Estos pavimentos son los primeros que se documentan en los comienzos de la dominación romana, ya en la segunda mitad del siglo " a.C., y en todo el siglo । a.C., y perviven como sistema de pavimentación durante parte del siglo I de la Era ${ }^{28}$. Suelen hallarse en lugares con un alto índice de romanización temprano, no tanto por la asimilación de la cultura romana por parte de los iberos, como por la presencia real en sus ciudades de itálicos, sobre todo en las importantes por su actividad comercial, administrativa o comercial. Es significativo el hecho de que en Carthago Nova, el mayor centro de explotación minera durante la República y el Alto Imperio, como lo fue también durante los bárquidas, fuese una técnica muy arraigada, según lo demuestra el gran número de tales pavimentos que en ella se han encontrado, la mayor parte desarraigados de su lugar primitivo.

El pavimento de Puente del Obispo cabría situarlo, por la sencillez del tema, en fecha temprana, si tenemos en cuenta que a medida que transcurre el tiempo la técnica se afianza en la Península y los temas y motivos se hacen más complicados.

Un mosaico de tema figurado se ha encontrado en Puerta de Tierra, Cádiz, fechado por la excavación hacia el cambio de la Era. Representa la disputa entre Apolo y Marsias ${ }^{29}$. Es un mosaico muy interesante que está implicando que en una ciudad tan fuertemente semitizada como Gades, en la cual el rito fenicio se conserva en el Heracleion, y la imagen del dios no está permitida, hay mosaicos con tema griego figurado en las casas particulares, indice de romanización.

Bl.anco, A., Mosaicos romanos de Itálica. Madrid 1978, pág. 44

Ramallo, S. F., Mosaicos romanos de Carthago Nova (Hispania Citerior). Valencia 1985 pág. 158.

PLAzouez, J. M. et al., "La mitología en los mosaicos hispanorromanos", AEspA, n." 59, 1986, págs. 101-162, fig. 5 


\section{GADES} $2,2)$.

Y aquella ciudad comercial (Gades) aún hoy florece (ESTRABón III,

Expongo a continuación una serie de citas e indicaciones acerca de Gades, ciudad Bética, en la que el elemento indígena convive con los pobladores itálicos y romanos. Es un ejemplo un poco particular, porque Gades no es una ciudad turdetana propiamente dicha, sino fue una ciudad fundada por los fenicios que tiene ya tarjeta de identidad propia en el panorama meridional peninsular. La tradición indica la fundación de Gades en el 1100 , según Veleyo PATÉRCulo 80 años después de la destrucción de Troya. Pomponio Mela también remonta la antigüedad de Cádiz y de su templo a la guerra de Troya $(3,46)$.

Las investigaciones llevadas a cabo en el área, concretamente por D. Ruiz Mata en el Castillo de doña Blanca (Puerto de Santa María), no remontan la fecha más allá del siglo vill a.C. Las estructuras habitacionales del Castillo de doña Blanca son de gran envergadura, acreditativas de la existencia de un verdadero emporio.

La situación de Gades, según Estrabón es: «... Está cerca de la boca del Betis..." (III, 5, 3). MELA $(3,46)$ señala acerca de Gades: "... Terminada por dos promontorios, en uno de los cuales hay una ciudad floreciente del mismo nombre que la isla y en el otro un templo de Hércules Aegyptus...".

Gades es una colonia fenicia y así siguió durante gran parte del dominio romano al que se incorporaría componente hispano estable. Conservó su idiosincracia, al menos durante época republicana. A este status de colonia fenicia alude Diodoro $(25,10)$ hablando de como a partir del 237 a.C., Amílcar comienza a conquistar Hispania. Probablemente presentaría en su época de esplendor el aspecto abigarrado, tumultuoso, propio de las ciudades comerciales ricas, en las que se mezclarían indiscriminadamente, semitas, griegos, hispanos turdetanos y de los más diversos lugares, en confuso desorden.

En el año 206 a.C., después de la derrota cartaginesa, comienza la conquista de Andalucía. Gades, en cuya ciudad se encontraban aún restos del ejército cartaginés, a pesar del parentesco étnico con los púnicos, pactó con Roma y se entregó (LIVIO, 28, 23,6): “Por estos días llegaron (en el 206 a.C.) fugitivos de Gades prometiendo entregar la ciudad y la guarnición cartaginesa que en ella había, con su jefe y escuadra..." Es explicada esta defección de la causa púnica, porque Gades no era en el sentido estricto de la palabra cartaginesa sino fenicia y por el particular 
carácter comercial de sus habitantes, a quienes interesaría mantener la paz, más beneficiosa para sus ganancias que la guerra, al menos en aquella época.

En el año 49 a.C., por haber favorecido la causa de César recibió el título de municipium civium romanorum (LIVIO, per. 111) de manos del dictador. De Augusto recibió el título de municipium Augustum gaditanum (según inscripciones). A partir de este momento el gobierno ya no estaba en manos de los sufetes, magistraturas únicas, sino de los quattuorviri. Estos ya están citados por CICERón cuando en un fragmento de su carta (ad fam. 10, 32) habla de la existencia del teatro en Gades.

Es desde esta fecha, consecuentemente con el advenimiento de los magistrados romanos, cuando la ciudad comienza a romanizarse. Porque en época de las guerras sertorianas, cuando Balbo obtuvo la ciudadania por los favores prestados a Pompeyo, aún no se hablaba el latín corrientemente, como cuenta CiCERón en Pro Balbo. Estrabón (III, 5, 3) significa que, según un censo hecho en su tiempo, existían en la ciudad 500 equites, es decir ciudadanos romanos, verdadera aristocracia del dinero, que probablemente como ciudad comercial que era ocupaban el primer puesto en el rango social de la misma. Acerca de esta cifra hay discrepancias, pues Nicolet a quien sigue F. Rodriguez Neila ${ }^{30}$, que ha llevado a cabo numerosos e importantes estudios sobre las familias de Cádiz, piensan que esta cifra, tan elevada, abarcaría no sólo a lo equites concretamente, sino también a los familiares. En cambio J. M. Blázquez cree que dado el volumen comercial de la ciudad esta cifra podría contemplarse como real ${ }^{31}$.

Pervivencias ancestrales se documentan en Gades como la de quemar vivos a hombres, tal es el caso que narra CICERon (ad fam. 10, 32) sobre Fadio, un soldado de Pompeyo, al que el quattuorvir Balbo, en el año 43 a.C., sobrino de Balbo I, enterró en lodo e hizo quemar vivo. Esta costumbre está atestiguada en Aulo GELIO, (N.A. 3, 14) quien la toma de Marco Catón el cual escribe que los cartagineses "enterraban a los hombres hasta medio cuerpo y encendían fuego a su alrededor». Parece que tal castigo de quemar vivos a los criminales proviene de una costumbre fenicia de Gades. César la suprimió en el año 61 a.C., durante su propretura, pero Balbo el Joven, descendiente posiblemente de fenicios, la emplea.

\footnotetext{
30 Acerca de los Balbos cf. Rodriguez Nella, J. F., Los Balbos de Cádiz. Sevilla 1973. Sobre Gades, del mismo autor: El municipio romano de Gades. Cádiz 1980.

${ }^{31}$ BlazQueZ, J. M., "Hispania en época julio-claudia”, Estudios sobre la Tabula Siarensis Anejos de AEspA, n." 9, 1988, pág. 220.
} 
$Y$ porque era una ciudad comercial, tiende a adoptar las costumbres romanas, ya que de esta manera facilita el comercio con los itálicos, con los romanos. El comercio en Gades tenía una larga tradición que remonta al motivo de su propia fundación.

Gran parte de la producción hispana, en general las materias primas, metales y salazones y algún producto manufacturado, eran exportados a través de Gades. Productos que llegaban no sólo a Italia, sino incluso a Oriente.

“... Sobre Gades se cuenta mucho. Porque los gaditanos son los que envian los barcos de comercio más grandes y más numerosos por el mar Nuestro y por el Mar fuera de las Columnas... en su mayor parte habitan el mar, mientras unos pocos se quedan en casa o viven en Roma". (Es. TRABON, III, 5, 3).

La ciudad de Gades controlaba desde su fundación las rutas atlánticas y africanas. Uno de sus puertos era Portus Hannibalis (MELA 3, 7). Cuenta Estrabón (III, 5,11$)$ acerca de las Cassiterides... "antes sólo los fenicios de Gades hicieron este comercio, escondiendo a todos su ruta, y cuando los romanos persiguieron a uno de estos navegantes para conocer aquellos mercados, éste hizo encallar su barco...".

Del urbanismo de Gades poco se conoce, porque se encuentra debajo de la ciudad moderna. La riqueza de la ciudad queda patente en el ajuar funerario de alguna tumba.

\section{El Heracleion}

Parece que se encontraba en la isla de Sanctipetri, a $18 \mathrm{~km}$, al sur de Cádiz. Como escribe Mela $(3,46)$ cuando explica la situación de Gades: “... Terminada por dos promontorios, en uno de los cuales hay una ciudad floreciente del mismo nombre que la isla y en el otro un templo de Hércules Aegyptus, célebre por sus fundadores, por su veneración, por su antigüedad, y por sus riquezas. Fue construido por los tirios. Su santidad estriba en el hecho de guardar las cenizas de Hércules; los años que tiene se cuentan desde la guerra de Troya. Sus riquezas son producto del tiempo..." ApIano (Iber. 1,2) afirma que el dios venerado era el de Tiro no el griego. El templo fue fundado por los fenicios.

A la pluma de SILIO ITÁlICO, $(3,14-30)$ se debe una serie de noticias acerca del templo fenicio, que parece pueden ser fidedignas ya que su fuente probablemente es Posidonio, como entre otras, que en los altares se mantiene permanentemente un fuego, y que no hay ídolo en el santuario, conforme a la costumbre semita de no representar a sus dioses. 
El santuario fue asiduamente visitado, no sólo por los fenicios, sino por los hispanos, por los cartagineses y más adelante por los romanos. A Hércules, el Melqart de Tiro, dios solar, sacrificaban para ganar su protección.

Según Livio $(21,21)$ Anibal después de haber tomado Sagunto se retiró a invernar a Cartagena en el 219 a.C. y pasado el invierno, al principio de la primavera "... Marchó a Gades a cumplir los votos que había hecho a Hércules y se ligó con nuevas promesas si le era próspero el futuro...".

En el año 145-144 a.C., Apiano, lber. 65 expone que los romanos estaban en Gades, haciendo sacrificios a Hércules, concretamente Fabio Máximo Emiliano, hijo de Emilio Paulo, el vencedor de Perseo, que fue enviado aquí a luchar contra Viriato.

En el año 68 a.C. el templo también fue visitado por César (SUETONio, César 7)... "Como cuestor le tocó (a César) la España Ulterior. Donde recorriendo las comunidades para administrar justicia por mandato del pretor, vino a Cádiz y advirtiendo que $c$ " el templo de Hércules había una estatua de Alejandro Magno, se echó a llorar, como avergonzado de su desidia, pues nada memorable había hecho a pesar de hallarse ya en la edad en que Alejandro había conquistado el orbe (también Dión CASS, $37,52-53)$.

Las pervivencias del culto a Heracles llegan hasta época imperial como se demuestra por las monedas. En las de la época de Adriano hay notas referentes a Hispania y concretamente a Hércules con clava, a sus pies el Betis echado. En otras se representa la proa de un barco y el letrero Herc(uli) Gadit(ano). En tiempos del emperador Caracalla éste mató a Cecilio Emiliano, procónsul de la Bética, por haber consultado el oráculo que se hallaba en el templo de Gades. Verosímilmente había preguntado sobre el tiempo de vida del emperador o algo semejante (DIÓn CASs. 77, $20,4)$. 